\title{
Investigating the Student Satisfaction of Combined Education Based on Learning Management System and Academic Participation
}

\author{
Research Article
}

\section{Daryadokht Masroor Roudsar ${ }^{1}$, Hamid Haghani ${ }^{2}$, Afsaneh Dehnad ${ }^{3}$, Ali Zabihi ${ }^{4}$, Maryam Ghasemi Shoub $^{5}$, Mostafa Akbarian Rokni ${ }^{6 *}$}

1, 2. Instructor, Faculty Member of Nursing \&Midwifery, Iran University of Medical Sciences, Tehran, IRAN.

3. Associate Professor, Faculty Member of Iran University of Medical Sciences, Tehran, IRAN.

4. Assistant Professor, Faculty Member of Babol University of Medical Sciences, Babol, IRAN.

5. Nursing Expert, Faculty of Nursing \&Midwifery, Babol University of Medical Sciences, Babol, IRAN.

6. Department of Nursing, Internal Surgery, Faculty of Nursing \&Midwifery, Iran University of Medical Sciences, Tehran, IRAN.

\begin{abstract}
Aim and Purpose: Considering the importance of nursing education, especially the use of modern educational technology to meet existing educational needs, the present study aimed to investigating the satisfaction and academic participation of nursing students who use combination education based on learning management system (LMS) and studied their degree of satisfaction and academic participation. Method: This is a descriptive cross-sectional study in which 229 undergraduate nursing students. After obtaining permission from the university's ethics committee and informed consent, demographic data form, satisfaction of combined education questionnaire of Zolfaghari et al.'s, the educational participation scale questionnaire of Frederick et al.'s was completed as a tool for collecting data. Data were analyzed by SPSS software version 23 and significance level less than 0.05, descriptive statistics, independent t-test, one way ANOVA, and Scheffe post hoc test and Pearson correlation. Findings: The vast majority had a moderate or lower familiarity with the LMS system (75.5\%). The majority did not easily access the LMS system (56.3\%). Only $2.2 \%$ of the units had high satisfaction and $40.2 \%$ had relative satisfaction and $57.6 \%$ had low satisfaction from LMS-based combination training. The mean and standard deviation of the educational participation score was $51.16 \pm 14.86$ and their behavioral subscale scores $69.68 \pm 16.48$ and the emotional subscale was $49.56 \pm 20.53$ and the cognitive subscale was $38.25 \pm 20.55 \%$. Conclusion: According to the results of the study, most of the research units had low satisfaction with LMS-based combination training, which could increase student satisfaction by using all the capabilities of the learning management system and the more interactive design of the combination training, as the majority of previous studies have shown high satisfaction with combined training.
\end{abstract}

Keywords: Satisfaction Combined Education, Learning Management System, Academic Participation, Nursing Students.

\section{Introduction}

The third millennium is an era of accelerating change and the world today is heavily influenced by technological change. One area that is heavily influenced by these changes is the field of learning and learning. So today, e-learning is one of the most promising methods for providing educational services. Technology makes it possible to provide training for staff at various locations and to ensure that all of them can be accessed on educational content, and also the additional costs of bringing in the instructor or sending out-of-town students to study curricula (1). Many educators try to combine different methods and believe that combining instruction is a promising approach to solving these problems, and this approach can be used

*Corresponding Author:

Mostafa Akbarian Rokni,

Department of Nursing, Internal Surgery, Faculty of Nursing\&Midwifery, Iran University of Medical Sciences, Tehran, IRAN.

Email: mostafa.akbarian_rokni@yahoo.com to benefit both e-learning and traditional education (2). Combined learning is a relatively new term, but its concept has been around for decades in areas such as virtual education (3). Combined learning in both industrial and organizational education as well as in education is growing rapidly and most educational institutions and organizations use a combination learning approach to deliver better services to their learners (4). Garrison and Vaughan have defined composite learning as a thorough integration of elearning and face-to-face learning (5).

Learning management system today has become one of the most important forms of deploying information technology in e-learning (6). The learning management system in the education section is about problem design, formulas, planning tools, workgroup and scoring mechanisms. In general, learning management system is a new approach to e-learning that is controlled by educators and, in addition to learning management, supervises student progress and facilitates the planning and evaluation process (7). Since nurses are important members of the health care system, their knowledge, knowledge and skills can play an important 
role in providing services to patients. In combined studies and learning management systems, it seems that all dams in the traditional classroom would be broken and lead to good results (8) and the diverse learning environment and the use of educational packages and the provision of new teaching methods and the role of faculty change can be considered as an important component of learning (9).

Academic achievement of university students and their related factors are among the priorities of research in education and issues of interest to university administrators. One of the key factors in the success of students is the notion of educational participation (10). Linking student behaviors and environmental conditions to the university will create a willingness to participate and enthusiasm in the individual and his success (11). The educational participation structure refers to the behaviors that are related to learning and academic achievement (12). The indicators and priorities of the programs and perspectives in the study and research of universities are the degree of educational participation and related factors that are of great interest to educational managers and the results of studies also show that those who have higher education participation than those with lower levels of enthusiasm for engagement show greater willingness to spend time and effort on homework and studies, and have more efficiency and insistence in dealing with problems and problems.

Considering the above mentioned and the importance of teaching nursing students, especially the use of modern technologies to meet existing educational needs, this study aimed to investigating the satisfaction and academic participation of nursing students who use combination education based on learning management system (LMS) and studied their degree of satisfaction and academic participation.

\section{Research Objectives}

Determine satisfaction of nursing students from combined learning based on learning management system.

Determining educational participation (behavioral, emotional and cognitive) of nursing students in the field of combined learning based on learning management system.

\section{History of Research}

Mohd et al., In 2016, conducted a study entitled Increasing the Students' Participation in Business Management through Consensus on Combined Education and Coaching Support in Malaysia. The purpose of this study was to examine the factors related to combination education and coaching and inclusive relationships that enhance the participation of students in learning. They used a researcher-made questionnaire that evaluated the students' behavior, experiences, feelings and perspectives on their passion for education. The results of their study indicated that there is a strong positive relationship between the satisfaction of the combined education and the support of the coach with the enthusiasm for the students' education.
In 2015, Lee and Hung discussed the benefits of using hybrid training in China. The goal was to design a virtual education system for the Tax Revenue Faculty and review the achievements of this educational system. They grouped their participants into three groups of traditional education, e-learning and combination education, and examined the students' satisfaction with these three types of training. The results of their study indicated that students who used combination training significantly improved their educational achievement than the other two groups. Also, students who have used traditional and combined education have stated that they want to use e-learning methods to use educational methods.

Jahedi and Mesbah in 2014 evaluated the impact of face-to-face training and the combination of general academic prerequisites on their subject-related lessons with technical students. Data were collected by written test and questionnaire. The results of the study showed that the effectiveness of face-to-face lessons was greater than combined courses, but the time saved for combined training students increased the grades of their other courses, so that they did not differ in the mean of the two groups.

\section{Research Methodology}

This study is a descriptive cross-sectional study. The researcher studied student participation and student satisfaction through demographic information and Frederick, Blomfild, Paris, and Satisfaction questionnaire of Zolfaghari and colleagues. The research population of this study was all undergraduate nursing students of the Faculty of Nursing and Midwifery of Iran University of Medical Sciences who were studying from the second semester to the sixth semester. Sampling method of this study was all based on entry criteria. Due to the limited research community, sampling was not performed and all of the eligible units were included in the study. A total of 229 undergraduate nursing students were selected from a total of 280 from the second to sixth semesters and entered the study using a total number based on input criteria. The reliability coefficient of the academic participation scale was calculated using Cronbach's alpha method. The Cronbach's alpha coefficient was 0.66 . In the study of Zolfaghari et al. (2008), to determine the scientific validity of the satisfaction questionnaire from combined education, the content validity and internal consistency of the instrument were determined using Cronbach's alpha method, which was 0.93.Cronbach's alpha coefficient, was obtained. To analyze the data, descriptive statistics and analytical statistics were used as needed. SPSS 23 software was used to analyze the data and the significance level was less than 0.05 . To conduct this research, the checklist of the use of the faculty members from the Learning Management System (LMS) in various nursing courses was prepared by the researcher and validated and evaluated by the consultant, including the control of the system's functionality, such as the number of uploaded files, the type of uploaded content (PDF, PPT, DOC, storyline, camtesia (mp4)), practice, test and quizzes, student feedback section, scoring section, members' view 
section when logging in, the message section, using the chat room, the news section, the reporting section, the virtual class section, and the questions section of the bank which was used by faculty members in teaching lessons and used by students.

\section{Findings}

\section{Descriptive Statistics}

The findings of the research show that most of the research units were female $(52.8 \%)$, in the range of 21-29 years old $(53.3 \%)$, single $(90 \%)$ and native of Tehran $(53.7 \%)$. The most interest was between the specialized courses in internal-surgical lessons (54.1\%) and the least interest in nursing management lessons $(0 \%)$. The vast majority had a relatively modest and lower familiarity with the LMS system (75.5\%). The majority did not easily access the LMS system (56.3\%).

\subsection{Analytical Statistics}

Objective 1: Determine satisfaction of nursing students from combined learning based on learning management system.
Table 1: Frequency Distribution and Numerical

Indices of Satisfaction Score from Combined

Learning Based on Learning Management System (LMS) based on the standard 0 to 100 in the research units of year 2017

\begin{tabular}{|c|c|c|}
\hline Satisfaction & Frequency & Percentage \\
\hline $\begin{array}{c}\text { High satisfaction } \\
\text { (Score 75\% and above) }\end{array}$ & 5 & 2.2 \\
\hline $\begin{array}{c}\text { Relative Satisfaction } \\
\text { (to 75\% score \%50) }\end{array}$ & 92 & 40.2 \\
\hline $\begin{array}{c}\text { Low Satisfaction } \\
\text { (Score less than 50\%) }\end{array}$ & 132 & 57.6 \\
\hline Total & 229 & 100 \\
\hline $\begin{array}{c}\text { Standard deviation } \pm \\
\text { average }\end{array}$ & $43.35 \pm 16.90$ \\
\hline $\begin{array}{c}\text { Highest score - Medium } \\
\text { - Lowest score }\end{array}$ & $0.00-44.85-86.03$ \\
\hline
\end{tabular}

As the table shows, the majority of the studied units (57.6\%) had little satisfaction with learning management based on learning management system (LMS).

Objective 2: Determining educational participation (behavioral, emotional and cognitive) of nursing students in the field of combined learning based on learning management system.

Table 2: Numerical Indices of the Academic Participation Scale and Its Subscales Based on the Standard of 0 to 100 in the Research Units of Year 2017

\begin{tabular}{|c|c|c|c|c|c|}
\hline $\begin{array}{c}\text { Subsidiary } \\
\text { Scale of } \\
\text { Academic } \\
\text { Participation }\end{array}$ & Average & $\begin{array}{c}\text { Standard } \\
\text { deviation }\end{array}$ & Middle & Lowest score & Highest score \\
\hline $\begin{array}{c}\text { Behavioral } \\
\text { participation }\end{array}$ & 69.68 & 16.48 & 68.75 & 0.00 & 100.00 \\
\hline $\begin{array}{c}\text { Emotional } \\
\text { partnership }\end{array}$ & 49.56 & 20.53 & 50.00 & 0.00 & 100.00 \\
\hline $\begin{array}{c}\text { Cognitive } \\
\text { participation }\end{array}$ & 38.25 & 20.56 & 40.00 & 0.00 & 100.00 \\
\hline $\begin{array}{c}\text { Educational } \\
\text { participation }\end{array}$ & 51.16 & 14.86 & 51.67 & 0.00 & 100.00 \\
\hline
\end{tabular}

This table shows that among the subscales of educational participation in the research units, the highest mean score for the subscale of behavioral participation with mean and standard deviation was $69.68 \pm 16.48$ and the lowest mean score for the cognitive subscale with mean and standard deviation was $38.25 \pm 20.56$.

\section{Discussion and Conclusion \\ First objective}

The results indicated that only $2.2 \%$ of the subjects had high satisfaction (75\% and above score) and $40.2 \%$ had relative satisfaction (score $50 \%$ to $75 \%$ ) and $57.6 \%$ had low satisfaction (less than $50 \%$ ) from combination of learning based on the Learning Management System (LMS). According to the results of the study, most of the studied units (students) had low satisfaction with LMS-based combination training. The research of Koohang et al., 2008 (13), Eslami et al., 2016 (14), and Zolfaqari et al., 2010 (15) contradict with our research.

\section{Second objective}

The results indicated that the mean score of students' academic participation was $51.16 \%$ (raw score 45.69 ) with a standard deviation of $14.86 \%$ (raw score of 8.92), and the subscales scores for their behavioral participation was $69.86 \%$ (raw score 15.15 ) with a standard deviation of $16.48 \%$ (raw score 2.64 ), and the mean score of emotional subscale was $49.56 \%$ (raw score 17.98 ) with a standard deviation of $20.53 \%$ (raw score 2.64) and the scores of cognitive subscales was $38.25 \%$ (raw score $12.65 \%$ ) with a standard deviation of $20.56 \%$ (raw score of 4.11 ) in the studied units, which 
the among the subscales of educational participation in the research units, the highest mean score was for behavioral participation subscale and the lowest mean score for the cognitive subscale. The results of the study by Casuso-Holgado et al. in 2013 (16) and Ghadampour et al. in 2015 (17) are in contradiction with our research. Findings of the research showed that most of the studied units (students) had low satisfaction from LMS-based combination training.

Given the enormous costs that the annual cost of equipping and upgrading the electronic and virtual systems of the university in order to keep pace with the new educational developments in the world-class universities, with the establishment of theoretical and practical workshops and appropriate training seminars in order to inform and strengthen the university faculty and students, it would be possible to increase the students' satisfaction and academic participation and their more academic achievement, until the university, the modern educational methods are not forgotten, and the university's educational quality is promoted and steps are taken to realize the success of third-generation universities and the implementation of a virtual development package, both virtual and hybrid, which is an integral part of it.

\section{References}

1. Derouin, R. E., Fritzsche, B. A. and Salas, E. (2005) E-learning in organizations. Journal of Management, 31(6), pp. 920-940.

2. Seung-Won, Y. and Lim, D. H. (2007) Strategic blending: A conceptual framework to improve learning and performance. International Journal on ELearning, 6(3), pp. 475.

3. Akkoyunlu, B. and Yilmaz-Soylu, M. (2008) Development of a scale on learners' views on blended learning and its implementation process. The Internet and Higher Education, 11(1), pp. 26-32.

4. Bonk, C. J. and Graham, C. R. (2012) The handbook of blended learning: Global perspectives, local designs, John Wiley \& Sons.

5. Garrison, D. R. and Vaughan, N. D. (2008) Blended learning in higher education: Framework, principles, and guidelines, John Wiley \& Sons.

6. Owens, J. D. and Price, L. (2010) Is e-learning replacing the traditional lecture? Education+ Training, 52(2), pp. 128-139.

7. Ramakrisnan, P., Jafar, A., Razak, F. H. A. and Ramba, D. A. (2012) Evaluation of user Interface Design for Leaning Management System (LMS): Investigating student's eye tracking pattern and experiences. Procedia-Social and Behavioral Sciences, 67, pp. 527-537.
8. Bahreini, M., Bijani, M., Rahmati, H. and Shahamat, S. (2011) The effectiveness of a multimedia training program on incidence of occupational exposure to contaminated sharp tools among nurses. Iran Journal of Nursing, 24(69), pp. 69-77.

9. Jamshidi, N., Abbaszadeh, A. and Najafi Kalyani, M. (2012) Comparison of Video \& Verbal Education on Satisfaction and Post-Operative Complications of Patients Undergoing Coronary Angiography. Journal of Fasa University of Medical Sciences, 1(4), pp. 233-237.

10. Walker, K. W. and Pearce, M. (2014) Student engagement in one-shot library instruction. The Journal of Academic Librarianship, 40(3), pp. 281290.

11. Abbasi, M., Dargahi, S., Pirani, Z. and Bonyadi, F. (2015) Role of Procrastination and Motivational Self-Regulation in Predicting Students' Academic Engagement. Iranian Journal of Medical Education, 15(0), pp. 160-169.

12. Pintrich, P. R. (2000) An achievement goal theory perspective on issues in motivation terminology, theory, and research. Contemporary educational psychology, 25(1), pp. 92-104.

13. Koohang, A., Behling, R. and Behling, S. (2008) Adding a new dimension to education: Students' perceptions toward hybrid/blended course delivery. Issues in Information Systems, 9(1), pp. 1-5.

14. Eslami, K. (2016) Different Methods of Medical Sciences Virtual Education in Iran and Assessment of their Efficacy; a Review Article. Educational Development of Jundishapur, 7(2), pp. 128-137.

15. Zolfaqari, M., Sarmadi, M., Negarandeh, R., Zandi, B. and Ahmadi, F. (2010) Studying the satisfaction of Nursing and Midwifery students and teachers from applying blended learning system. Iranian Journal of Nursing Research, 3(10-11), pp. 99-109.

16. Casuso-Holgado, M. J., Cuesta-Vargas, A. I., Moreno-Morales, N., Labajos-Manzanares, M. T., Barón-López, F. J. and Vega-Cuesta, M. (2013) The association between academic engagement and achievement in health sciences students. BMC Medical Education, 13(1), pp. 33.

17. Ghadampour, E., Farhadi, A. and Naghibeiranvand, F. (2016) The relationship among academic burnout, academic engagement and performance of students of Lorestan University of Medical Sciences. Research in Medical Education, 8(2), pp. 60-68. 